\title{
AWARENESS OF MATERIALITY IN TIME AND CONDITION. THOUGHTS ON THE RELATION BETWEEN ART HISTORY AND CONSERVATION
}

\section{HUTH Andreas ${ }^{1}$ STAHLBUHK Katharine ${ }^{2}$}

\author{
1 Technische Universität Berlin- Institut für Kunstwissenschaften und Historische Urbanistik; andreas.huth@ \\ tu-berlin.de \\ https://orcid.org/0000-0001-7527-1073 \\ 2 Bibliotheca Hertziana - Max-Planck-Institut für Kunstgeschichte; stahlbuhk@biblhertz.it \\ https://orcid.org/0000-0002-7777-0463
}

ABSTRACT: Art historical research needs to consider the materiality of artefacts, but the character of the material and the state of preservation of any object change over time. Today's restoration and conservation sciences provide the basis for present research in the field of history of art and architecture. Following this premises and with some examples from current research projects our contribution tries to show how much the contemporary academic Art History can benefit from the material and technical knowledge of conservators.

KEYWORDS: Restoration, conservation ethics, art history, wall painting, sgraffito

Restoration science and art history both encompass the day-to-day interaction with objects of material culture such as artifacts, artworks, and buildings. Often the disciplines profit from one another in practice, for example in relation to issues surrounding production, dating, localization, the attribution to an artist, or the state of preservation. The two disciplines also both ascribe to international principles of ethical conservation, even if approaching them from different angles. In the two fields there is common agreement that historical objects should be protected in their entirety, that is including all original information associated with the object, and that this should be the basis of all further research. However, despite this common ground, a certain distance between the disciplines remains. Whereas restorers often do not have much use for the discussions surrounding art historical investigations and its humanities-based approach, art historians only occasionally take conservation practices into consideration, thereby viewing them as a kind of skilled craft or auxiliary discipline. As a result, the potential inherent to interdisciplinary cooperation or intensive specialized exchange often goes untapped-to everyone's disadvantage. 
Currently both fields are facing new challenges, the scope of which are almost to far-reaching to grasp. Due to fundamental shifts in the traditional cultural canon, the immaterial value of cultural heritage is no longer a matter of assumption. Capitalist economy reduces objects to their market and added values as determined by auctions and special exhibitions. Obsolete national narratives are being resurrected. Above all, new media are calling the significance of authentic sources into question. It is not possible to simply carry on as before. Restoration science and art historical research must confront the questions as to how to deal with these challenges and how these issues will develop in the coming years. A key problem is the issue of preserving material cultural heritage. Engaging with the problem of how to define the ethics of conservation at this time-a process fostered and initiated by the Florentine conference-must be carried forward and accompanied by the courage to make binding demands. From our perspective as art historians and restorers, a more intense cooperation, which is based on mutual acceptance, respect, and curiosity, represents an approach whose significance is not to be underestimated. We would like to advocate for this approach with the following examples from our own scientific practice and to demonstrate that research in the history of art and architecture can profit from the restoration sciences, and, conversely, that the art historical reassessment of art objects can heighten sensibilities for certain issues of conservation.

By way of two case studies, the present contribution will demonstrate how art historical interpretations may be modified and enriched via an exchange and interaction with restoration practices.

In the Chiostro Verde of Santa Maria Novella in Florence is one of the largest wall painting cycles of the 1430s, representing 36 scenes of the Genesis and painted mainly in monochrome green. ${ }^{1}$ There are still many unresolved questions regarding the cycle, its attribution, dating, etc., which, however, will not be addressed here. Rather, the focus will be the cycle's complicated but remarkable and long conservation history, which is emblematic of the discipline at large in its evolution and methodology (Felici/Pini/Vigna 2008; Stahlbuhk 2011; Bandini/Felici 2014). ${ }^{2}$ Moreover, this example offers the opportunity to question our current scholarly practices and our ethical principles in and how we, the scientific community "handle" cultural goods.

Due to the poor state of conservation, any aesthetic or historical reflection about these murals cannot advance without the direct exchange with the restorers or the relative documentation. Possible causes for the cycle's degradation, whether they can be tied to intrinsic and extrinsic factors of the specific painting technique (C. Lalli and A. Felici in: Frosinini 2019), ${ }^{3}$ or whether they can be attributed to the architectural environment and its use over the centuries cannot be treated in detail in the present study. ${ }^{4}$ Nor it will be possible to fully consider the methodological

\footnotetext{
1 On the iconography of the cycle see: Stahlbuhk (2019) and McAlister (2003) with references to the older bibliography.

2 For a reconstruction of the conservative operations effectuated in the Chiostro Verde see: Felici/Pini/Vigna (2008); Stahlbuhk (2011); Bandini/Felici (2014).

3 On the technical execution (and its variety) of the so-called verdeterra-paintings as well as the conservative problems related to the same see Felici/Pina/Vigna (2008) and the contributions by C. Lalli and A. Felici in: Frosinini (2019).

4 For a critical summary of the sources, which refer to the state of conservation or the use made of the cloister over the centuries, see the literature cited in note 1 and 2.
} 
significance of the different (evolutionary) stages and techniques regarding the detachment of murals in general. ${ }^{5}$ In line with the main topic of the present contribution, that is, the absolute necessity of an interdisciplinary approach in "handling" cultural goods, only those exemplary conservative actions that had a direct impact on how the paintings look today, will be mentioned in order to broach onto a wider discourse of conservation ethics.

Fortunately, archival documents offer a substantial insight into the development of conservation practices for the Chiostro Verde, mainly from the late $19^{\text {th }}$ century to the present. However less documented, it appears that people were already aware of the painting's poor state of conservation in the centuries immediately following their execution (Baldinucci, ed. 1845 [1681-1728], vol. 1, 449; Fineschi, 1790, 42-43). ${ }^{6}$ It is most likely that the most significant decay of the pictorial decoration in the cloister occurred in the 19th century, when it was, among other things, temporarily transformed into a stable for the horses of the Austrian cavalry (Lunardi 1983; Stahlbuhk 2011). ${ }^{7}$

Regarding the condition of the murals, a document from the Regional Office for the Conservation of Monuments of 1901 cites: "Nel Chiostro Verde, [...], gli stupendi affreschi di verde terra, che gli dettero il nome, si distaccano dal vivo della muraglia e si polverizzano per effetto dell'umidità, in altri tempi penetrate nelle pareti." ${ }^{8}$ Also, the committee of the Roman ministry, citing a detailed report by Guido Carocci ${ }^{9}$ of 1902, confirmed the disastrous state of the paintings as it mentions a "perdita quasi certa, [...], non troppo lontana". ${ }^{10}$ This disastrous situation was the starting point for a long series of highly invasive interventions on the murals, the consequences thereof are manifest in the current state of conservation.

In the first years of the $20^{\text {th }}$ century, the restorer Domenico Fiscali (1858-1930) was the protagonist for the conservation of the Chiostro Verde. ${ }^{11}$ He detached six murals in the cloister

\footnotetext{
${ }^{5}$ For an overview on the detachment of murals see: Paolucci (1990); Bonsanti (1993); Ciatti (2009), 208-239; Ciancabilla (2009).

${ }^{6}$ Baldinucci (ed. 1845 [1681-1728]), vol. 1,449: “[...] colpa del tempo, e forse anche della poca cura, gonfiato forte l'intonaco, era facil cosa che non vi si porgendo rimedio, fosse il tutto caduto a terra. Ma vaglia la verita che io non avrei giammai immaginato, che fosse occorso tanto presto si fatto accidente, [...]". Fineschi (1790), 42-43: "le pitture sono in molti luoghi quasi affatto smarrite".

${ }^{7}$ For the use of the cloister as a stable see the references cited in: Lunardi (1983); the documents of the Archivio Storico delle Gallerie Fiorentine cited in Stahlbuhk (2011), 113-117.

8 Archivio Storico del Comune di Firenze (ASCF), CF9244, Affari Straordinari, Santa Maria Novella e Santa Croce.

9 On Guido Carrocci see the entry by Papaldo (1977).

${ }^{10}$ Archivio Centrale di Stato (ACS), Roma, Direzione Generale Antichità e Belle Arti del Ministero della Pubblica Istruzione, IV versamento (dal 1908 al 1959), Div. 1, 1913-1915, busta 441.
}

11 On Domenico Fiscali see: Rinaldi (1998). 
between 1903 and $1911 .{ }^{12}$ Among these were the Deluge and the Drunkenness of Noah depicted by Paolo Uccello. ${ }^{13}$ The operations undertaken by Fiscali (with his so-called sistema Fiscali) were highly appreciated by his contemporaries. ${ }^{14}$ That explains why, initially, the local and state authorities intended to support the detachment of the whole cycle, although economic reasons first interrupted and then definitely stopped Fiscali's operations. ${ }^{15}$

In many ways, the Chiostro Verde was a testing ground for an interdisciplinary approach already in that first decade of the $20^{\text {th }}$ century. The sources bring to light, for example, discussions about the compatibility of the materials employed in the detachment and in the creation of the new support that involved engineers, restorers, and art historians. The major question, as to whether the detachment as such should be regarded as a valuable and ethically acceptable intervention, underlies the discussions in a variety of documents. Enthusiasm for technical progress, however, was the main criteria in those early attempts of salvaging the murals. In this regard, it is signifcant that Fiscali succeeded in detaching Uccello's Deluge in a single piece "eliminando cosi i tagli che fino ad oggi si erano resi indispensabili per la smisurata grandezza di quelle superfici dipinte." 16

As mentioned above, the interventions by Fiscali came to an end due to economic reasons. The availability of financial resources, to this day, is one of the main problems in the conservation, maintenance and the quality of individual restoration campaigns. The decade following Fiscali's restoration, the 1920s, where in fact characterized by a harsh public polemic on the devastating

12 The first mural Fiscali detached in 1903 was the lunette of the second bay on the southern wall of the cloister representing the Departure from Egypt and Separation of Abraham and Lot and the Entrance of Lot in Sodom. Three years later, in 1906, he detached the lower register of the same bay with the Capture of Lot and the Benediction of Melchisedec. In 1907 Fiscali detached the polychrome $14^{\text {th }}$-century Crucified Christ with Saint Dominic and Saint Thomas Aquinas in the lunette of the last bay of the western wall. Fiscali then, still in 1907, detached the Deluge and in 1909 the Sacrifice and Drunkenness of Noah, both painted by Paolo Uccello and located in the fourth bay of the eastern wall. His last intervention in the Chiostro Verde was the detachment of the Expulsion from Paradise in the lunette of the second bay of the eastern wall.

13 On the detachment of these murals see also the contemporary article by Campani (1910).

14 ASCF, CF9040, Belle Arti, Affari Generali dell'anno 1910, fascicolo 110 Santa Maria Novella (contains floating documents of earlier years), the ministerial committee wrote on the $12^{\text {th }}$ February 1904: "che l'operazione di distacco è stata compiuta con vera perfezione [...]. E tanto più i sottoscritti debbono esprimere la loro piena sodisfazione per i risultati ottenuti, se considerano le deplorevoli condizioni di deperimento nelle quali sono ridotti tutti in generale gli affreschi che adornano le pareti di questo chiostro. Le dubbiose speranze di salvare dall'estrema rovina queste opere di tanto valore artistico possono dirsi oggi rinfrancate dall' esito addirittura completo di questo tentativo compiuto dal Sig. Fiscali [...]". Similarly in 1909 judging the detachment of the Drunkenness of Noah one can read: "compiuti dal restauratore Sig. Domenico Fiscali con ogni cura e diligenza e dell' ottima riuscita". Illuminating is also a later journalist article which referred to the detachments by Fiscali from the beginning of the century. The journalist compared the state of the paintings before the restoration by Fiscali as 'dead bodies, which remained in water for several days', reporting also a greenish dust on the pavement underneath the murals. The operations by Fiscali are described as "miracolo"; cfr. La Nazione, Dal Chiostro Verde alla clinica romana, $4^{\text {th }}$ June 1943.

${ }_{15}$ See the many documents in ASCF, CF9040. For example, due to economic reasons, in 1905, the central committee (beside other members there were Corrado Ricci and Camillo Boito) proposed to limit the detachment to the murals attributed to Paolo Uccello.

16 ASC, IV vers. op.cit. 
condition of the cloister. ${ }^{17}$ Restoration of the murals began again only in 1929 with Amedeo Benini. ${ }^{18}$ Differently than in the previous campaign, the intention was to leave the paintings in their original location, thus avoiding the complicated and expensive process of detachment. The first murals Benini worked on were Paolo Uccello's Creation scenes. ${ }^{19}$ The sources are full of descriptions of the disastrous state of the pictorial surface, which makes the legibility of the painting today quite surprising. Benini focused his intervention on the consolidation of the surface..$^{20}$ The reviving substances applied by Benini to the murals most likely caused the major damage we see today, accelerating the destructive effects of the humidity and salt migration. In fact, only three years after his operations on the Creation, in 1934, the documents cite "da pochi mesi a questa parte, tutto ciò che di vivo e apparentemente brillante era tornato in luce, è oggi smorzato e in parte addirittura svanito". ${ }^{21}$ What makes the case study on the Chiostro Verde particularly interesting and relevant to the topic of this publication is the possibility of juxtaposing written sources with historical photographs of the murals. Two photographs by Alinari from 1930 and 1933 (Fig. 1 and 2), for instance, are evidence for the massive abrasion the pictorial surface has suffered as a consequence of the substances used in the consolidation by Benini. The later photograph of 1933 precedes the detachment of this scene, carried out a decade later, in 1941, by Mauro Pellicioli (1887-1974) of the Istituto Centrale di Restauro, under the direction of Cesare Brandi. ${ }^{22}$

17 The polemic was raised through an article by Ardengo Soffici with the title Affreschi di Paolo Uccello minacciati da rovina in La Nazione on 3rd January1929, which was followed by several other contrasting articles on the same journal.

18 On Amedeo Benini see: Gurrieri (1998).

19 Beninis description of the condition evokes a devastating state of conservation (ASCF, CF9118, 1930): "[...] si trovava in condizioni cattivissime. Tanto da dettare grande pensiero e precauzione per il restauro da eseguirsi che sembrava inutile qualunque tentativo, [...]".

20 See the annotations by Benini in ASCF, CF 9118: "Passato poi una soluzione per ridare a tutto l'affresco una parte di quella vivacità che col tempo era quasi totalmente distrutta" and "ravvivando quanto più si è potuto".

21 ASCF, CF9135, 1934.

22 This collaboration between the Florentines with the newly established Roman Istituto Centrale di Restauro is of high interest. Cesare Brandi effectuated a site inspection in 1941. He affirmed that the restoration should be granted by the ICR, even if the bad state of conservation would not permit a saddisfactory result (Archivio Storico dell'Istituto Centrale di Restauro (ASICR), f. AS0129: „sebbene non rappresenti, dato lo stato fatiscente, opera di particolare soddisfazione per l'Istituto di Restauro; dovrebbe essere condotto da questo, perché le difficoltà sono tali che non possono essere superate dalla comune prassi dei restauratori privati." Mauro Pellicioli (on him see Panzeri (1996); Rinaldi (2014)) detached five murals: the two Creation scenes, the Assassin of Cain, as well as the lunette and the lower register of the following bay illustrating the Construction of the Ark and the Entrance into the Ark. 


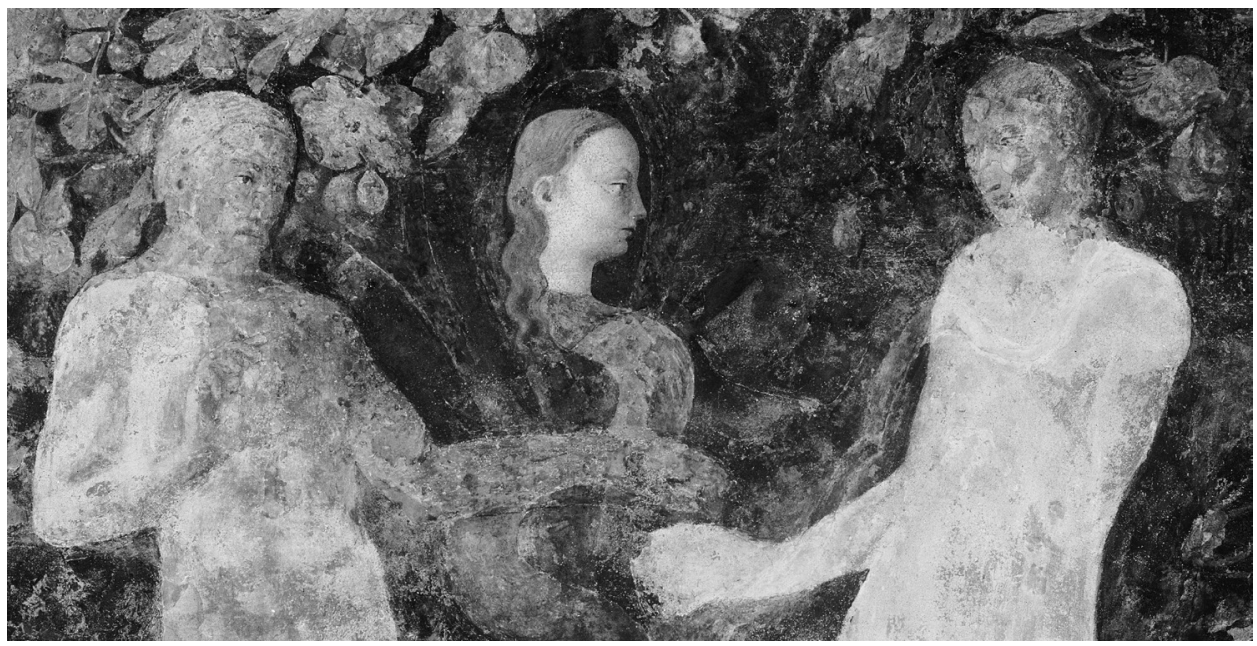

Fig. 1 Santa Maria Novella, Chiostro Verde, Paolo Uccello, Original Sin (detail), Photo: Alinari N. $4027 \mathrm{~B}, 1930$.

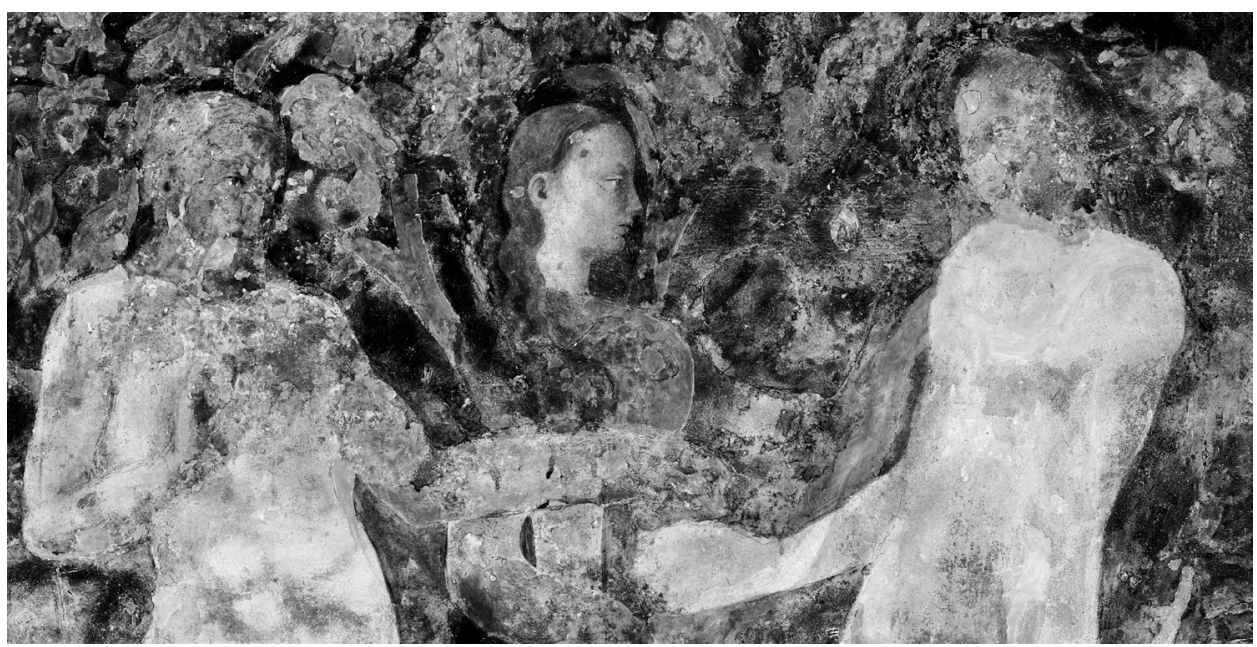

Fig. 2 Santa Maria Novella, Chiostro Verde, Paolo Uccello, Original Sin (detail), Photo: Alinari N. 4027 D, 1933.

The remaining murals were detached in the 1950s by Leonetto Tintori (1908-2000) and were then relocated in situ. ${ }^{23}$ This last decision is described in the sources as an "experiment" ${ }^{24}$ since the authorities were well aware of the continuous increase of air pollution and the insalubrious mural structures of the Chiostro Verde. What the scientific community and the local conservation

${ }^{23}$ See Leonetto Tintori's book on restoration of murals Antichi colori su muro. Esperienze di Restauro, Florence 1989. Tintori also intervened on the detached murals by Uccello in occasion of the exhibitions "Mostra dei Quattro Maestri del Rinascimento" in 1954 and the "Mostra di affreschi staccati" in 1957. Some documents on the restoration campaign by Tintori are preserved in the Florentine Ufficio Restauri, Archivio Tintori, faldone Chiostro Verde.

24 Beside other Ugo Procacci expressed his contrary opinion "assolutamente da sconsigliare", 14th July 1960; ASCF, CF9236. 
officials could not anticipate was the devastation caused by the flood in $1966 .{ }^{25}$ The water, and all the substances dissolved in it, reached nearly half of the lower register. All detached murals were transported to the laboratories of the newly founded Opificio delle Pietre Dure, where a long conservation process was undertaken. The return of the paintings into their original collocation in the early 1980s was accompanied by a vivid debate about the appropriateness of such a decision (Bonsanti, 1992, 222-223).
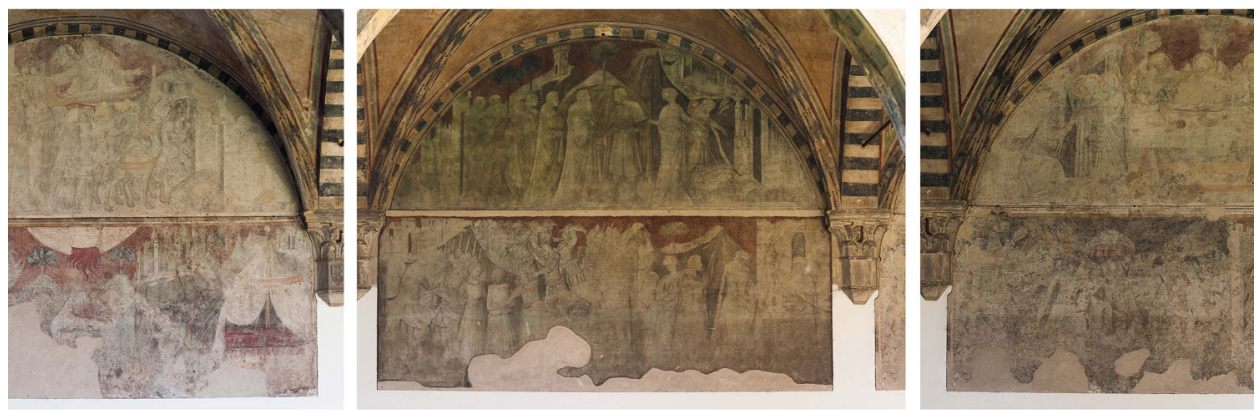

Fig. 3 Scheme of the first three bays of the southern wall in the Chiostro Verde, Santa Maria Novella.

The visual clarity of the single murals and of the cycle as a whole is today hardly compromised. The general condemnation of the euphoric age of stacchi and strappi is mostly justified, and in the case of the Chiostro Verde, where Tintori detached also all the sinopie of the cycle, there is an actual problem in conservation and access to the works, as the sinopie are stored in an inaccessible deposit in questionable conditions. However, returning to the importance of interdisciplinarity and the exchange of knowledge between the disciplines of art history and conservation, I want to conclude with the following reflection: Fig. 3 shows, at center, the first scenes detached by Fiscali (respectively the lunette in 1903 and the lower register in 1906). A general look at the southern wall, including the immediate adjacent bays - with murals detached more or less 50 years, and several interventions later - those detached by Fiscali still preserve, albeit their poor state of conservation, a much more greenish, and therefore (art) historically speaking more "original" appearance than their immediate neighbors. This being said, I do not intend to promote a prostacco turn, but to recall the necessity of context even in judging former practices of intervention and the necessary effort to understand the reasons for the conditions in which an artwork can be found at present.

${ }^{25}$ For some notions on the Chiostro Verde see Shearman (1967); Ragghianti (1966); Procacci (1970), 121. 


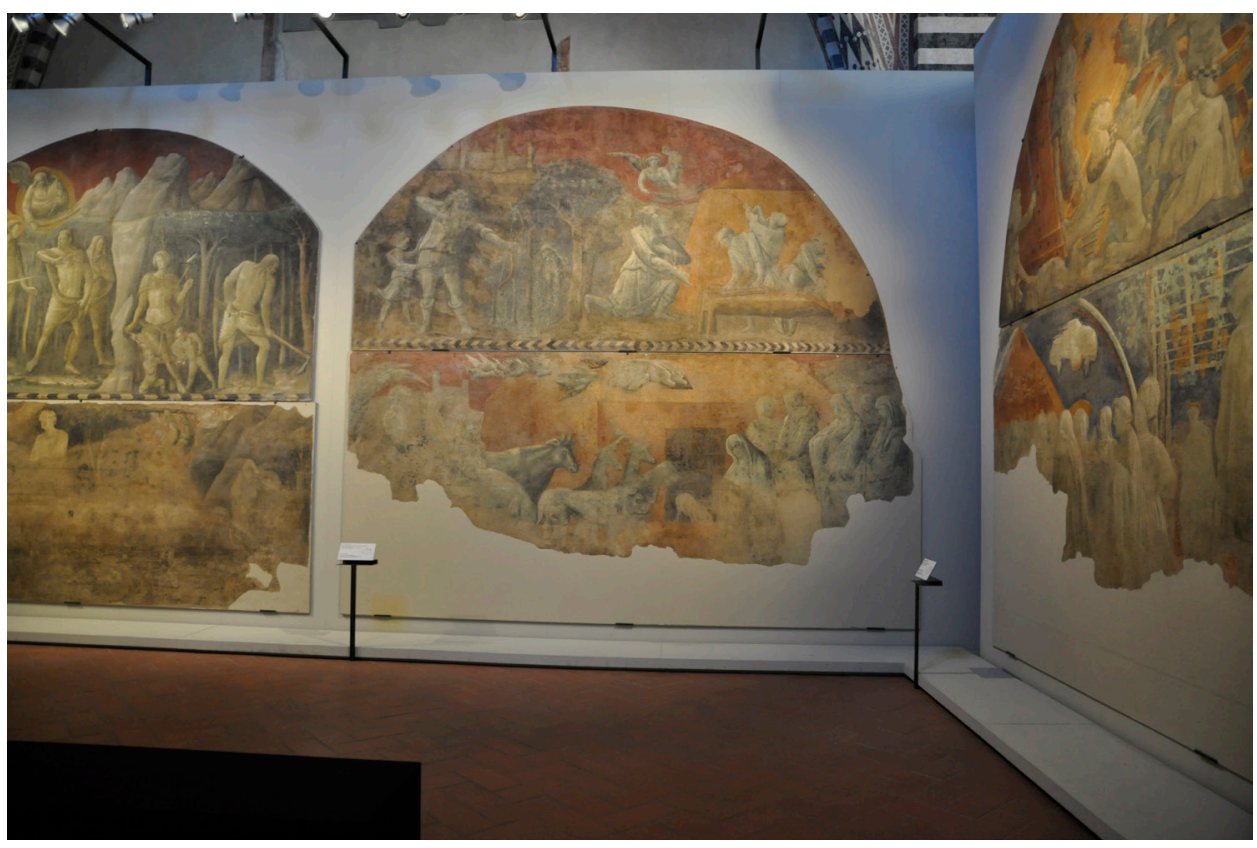

Fig. 4 Display of the restored murals of the Chiostro Verde in the adjacent refectory, Santa Maria Novella.

Today, the scientific community, like in the early 80 s, is again confronted with the question of relocation and therefore accessibility, usability, philology and conservation. Following the recent restoration campaign on the murals of the first four bays of the eastern wall (including the scenes attributed to Paolo Uccello) (Frosinini, 2019), the detached paintings have been located on huge panels in the ancient refectory of Santa Maria Novella, which is adjacent to the Chiostro Verde (Fig. 4). The hanging or musealization of these scenes surely enhances the durability and maintenance of the works, which would be hardly compromised in their original location due to continuous infiltration and air pollution. However, the installation of these eight murals evokes a chapel or oratory rather than the wall of a cloister. Moreover, it ignores the original height of the paintings from the ground (both curatorial decisions forced by the architectural space of the refectory), which misleads the beholder and disregards a historically acceptable 'reconstruction. The current state of the Genesis-cycle, though, touches crucial ethical aspects of conservation practices: should we guarantee the conservation for future generations, at least of the masterpieces of the cycle? Is it then tolerable to not allow the visitor to experience them in their original location by breaking up the continuity of the cycle? And if so, can we accept that those parts, which are not by the hand of a major artists, deteriorate due to the general increase of air pollution? - These are difficult questions which require serious, carefully studied answers by an interdisciplinary pool of scholars who believe that it is absolutely necessary to discuss these problems in interdisciplinary settings the absolute necessity to discuss. Only by debating the advantages and disadvantages might knowledge be generated and contribute to the field of ethics in conservation. 
As we have seen, art historical research benefits from competencies in the field of conservationand can assist in recognizing and communicating the value of monuments. In recent years the scientific interest for sgraffito decorations has increased and has paid special attention to issues of materiality and generally addressed questions of technology. ${ }^{26}$ As part of our contribution, I would like to offer some Florentine examples that shed light on the importance of the restoration sciences relative to many questions impacting research in the field art and architectural history. ${ }^{27}$ The residence of the Arte della Seta (Fig. 5), ${ }^{28}$ the powerful Florentine guild of silk traders and weavers, is located on one of the narrow alleys behind the Palazzo della Parte Guelfa, not far from the Loggia del Mercato Nuovo and Pietro Tacca’s famous bronze boar, Il Porcellino.

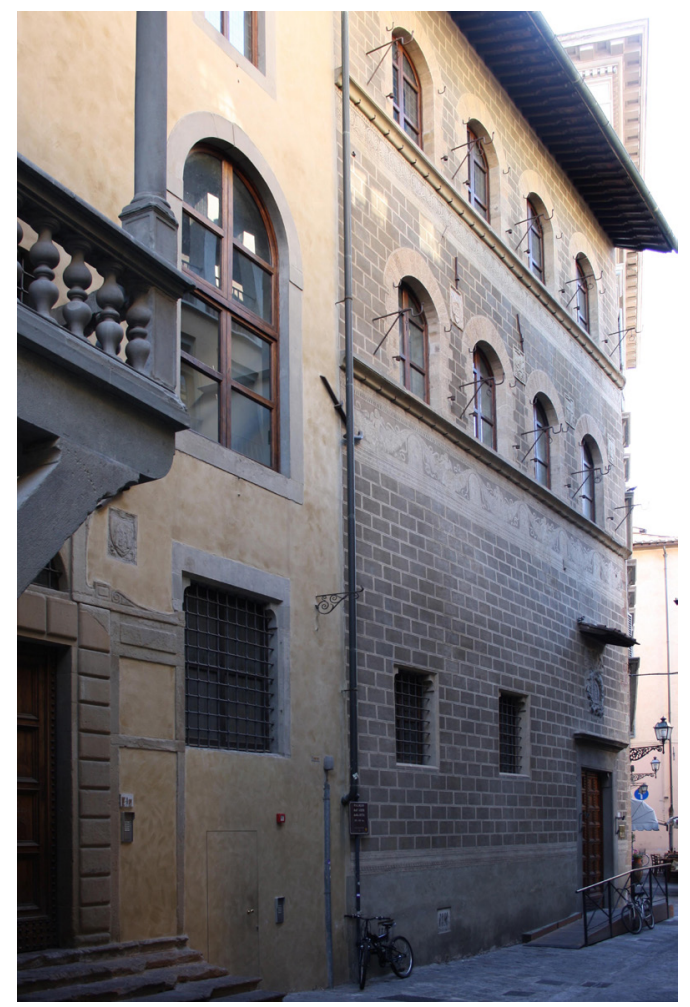

Fig. 5 Residenza dell’Arte della seta, Florence, situation 2016.

26 E. g. the recent conference "Sgraffito in Change" in November 2017 in Hildesheim/Germany. The proceedings will be published this year.

27 This text is based on the research for my $\mathrm{PhD}$ thesis "Florentiner Sgraffito-Dekorationen des 14. und 15. Jahrhunderts. Erfindung, Technologie, Bedeutung" (Berlin 2016), which will be published next year as part of the series "Italienische Forschungen des Kunsthistorischen Instituts in Florenz - Max-Planck-Institut". I am very grateful to my PhD supervisors Wolf-Dietrich Löhr and Gerhard Wolf, who have supported my work with their constructive criticism and encouragement. An overview of the history of the Italian sgraffito decorations with focus on Florence provide Thiem/Thiem (1964) and currently Huth (2019).

28 Residenza dell'Arte della Seta, Via di Capaccio, 3, Florence was built around 1385 for the Arte di Por Santa Maria. Benzi/ Bertuzzi (2006), 61-7. 
Around 1460 the building was adorned with a sgraffito facade showing a depiction of ashlar work, a frieze with putti, garlands, and the guild's symbol (Huth, 2016, vol. 1, cat. no. 24; Thiem/ Thiem, 1964, cat. no. 25, 70-1). However, in 1921 the building was reconstructed and the facade was redesigned - with significant changes, as evinced by comparison. Not only the remains of the Quattrocento decoration have been lost, but so have the original motifs and structure of the facade's design as well as all information regarding its material and technical execution. Today, the facade shows a strange brownish coloring, and the lighter ornaments have a drab or yellowish tone. A similar situation is evident on the Palazzo Corsi in Borgo Santa Croce, ${ }^{29}$ which was recently renovated. ${ }^{30}$ The sgraffito facade largely dates back to $1938 .{ }^{31}$ Only small portions of the original decoration were preserved as references. Before the most recent renovation, it was possible to distinguish between original and renovated elements, but now the entire surface has a uniform appearance, as the result of a highly questionable conservation approach (Fig. 6). Whenever the existing standards of conservation ethics are ignored, this needlessly complicates any examination. The treatment of this facade is truly regrettable, especially given that there are two exemplary restored sgraffito facades in Florence, namely those of the Palazzo Dietisalvi Neroni and the Casa Lapi. ${ }^{32}$ In the case of Palazzo Corsi, one hopes that a meticulous preliminary examination and a complete documentation of all interventions exist. Precise and publicly available documentations of restoration measures form the basis of later research. Therefore, such documentation is an important joint source for restoration practice and art historical study.

29 Palazzo Corsi, Borgo S. Croce, 19, Florence was built around 1420. The original sgraffito decoration can be dated to the same time. Huth 2016, Diss, vol. 2, cat. no. 14; Repertorio (14 August 2018) (as Palazzo Gherardi); Thiem/Thiem (1964), cat. no. 10, 58 (as Palazzo Morelli).

30 The renovation took place in 2017. The building is currently used as a school.

31 "Importanti restauri ad alcuni palazzi fiorentini," in: La Nazione, 9 March 1938. Referencing municipal architect Fabbrini, Christel and Gunther Thiem write, that the reconstruction had already taken place in 1917. See Thiem/Thiem (1964), cat. 10, 58 .

32 Casa or Palazzo Lapi, Via Michelangelo Buonarroti, 13, Florence was built around 1455. The sgraffito decoration was executed at the same time. The artist is unknown. Huth 2016, vol. 2, cat. no. 23; Repertorio (14 August 2018) (as Palazzo Lapi); Thiem/Thiem (1964), cat. 15, 64. On the restoration: Gualandi (2007), 201. Palazzo Dietisalvi Neroni, Via de’ Ginori, 9, Florence was built/reconstructed around 1444-7. The sgraffito facade is contemporary; Huth (2016), Diss., vol. 2, cat. no. 19; Repertorio (14 August 2018) (as Palazzo Gerini); Thiem/Thiem 1964, cat. 12, 59-60 (as Palazzo Gerini). On the restoration of the Palazzo Dietisalvi Neroni: Bandini et al. (2001), 60-89. 


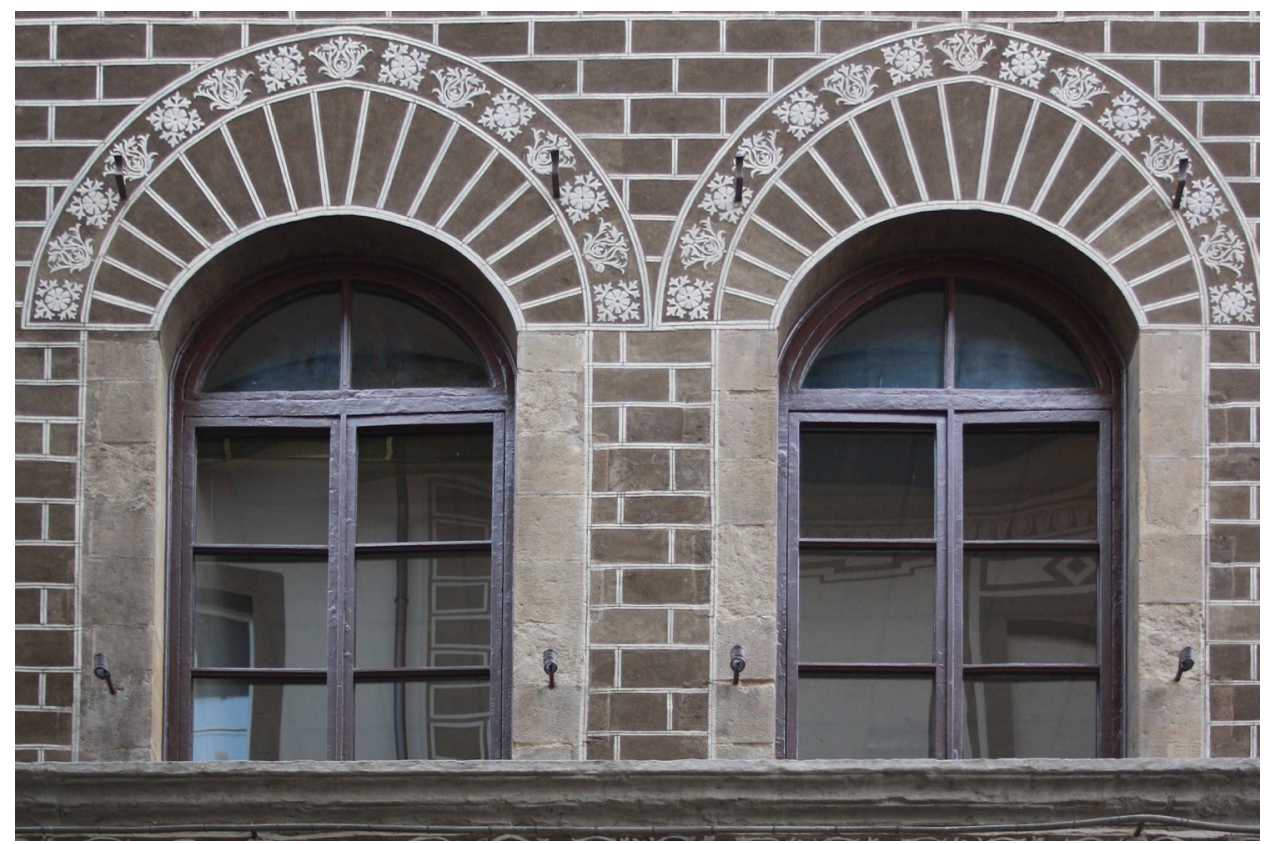

Fig. 6 Palazzo Corsi, Florence, facade after the 2017 restoration.

As with the Arte della Seta residence, the facade of the Palazzo Corsi shows an obtrusive brownish coloring. One can exclude the possibility that this corresponds to the original Quattrocento coloring, because no plaster or whitewash of the fourtheenth or fifteenth century contains such pigments. Furthermore, the current surface has a scratched decoration, but painted. Color and technique are essential in producing the aesthetic effects of a building front - or any other pictorial object. Therefore, in terms of art historical research, questions of color and technique are not secondary matters; they are of equal importance as any other topic of discussion, such as problems of dating, the transfer of motifs and ornaments, the attribution to a specific artist or artisan, or the overarching cultural context.

To learn more about early sgraffito techniques, it is helpful to explore decorations without such later interventions. Although few such examples exist, among them are the remnants of the former courtyard of Villa La Pietra near Florence, ${ }^{33}$ executed around 1470, more or less the same time as the original facade of the Arte della Seta residence. Coated with a layer of plaster in the sixteenth century, the surface was exposed to the elements for the relatively short period of one hundred years. The microscopic examinations of samples taken from the facade have shown that the plaster contains a black pigment made of burned plants (Huth, 2014, 12-13). A similar conclusion was drawn from an examination of the plaster of Casa Lapi, carried out by the restorer Daniela Valentini in 2005. Astonishing is the modest contrast between the colored plaster and the whitewash, which cannot be considered a consequence of the leaching process.

33 The Villa La Pietra, today part of New York University, was built as a villa suburbana for Francesco Sassetti in the 1460s; Lillie (2005), 180ff. On the sgraffito decoration executed around 1470: 202-4, 228; Huth (2016), 84-6. 
Other sgraffito facades that have not undergone later interventions also lack intense contrast, which has commonly been considered as key feature of this kind of wall decoration. This is amazing, given that the art historical perception of sgraffito is based on a bold bichrome contrast and also that the purpose of restoration is often defined as the renewal or reconstruction of this contrast, as demonstrated in examples mentioned above. However, an analysis of the material and execution of these unrenovated examples argues for a new perspective. The technique was not developed as cheap substitute for bichromatic marble incrustations, but as a simple regulation of joints. The earliest known sgraffito decoration in Florence can be found in the so-called Chiostro antico in the complex of the Florentine monastery of S. Croce. Dating circa 1325 and located in the little-known narrow cloister behind the Cappella Pazzi in S. Croce, it covers the brickwork of the ground floor arcades below the Corridoio del Noviziato (Fig. 7). ${ }^{34}$

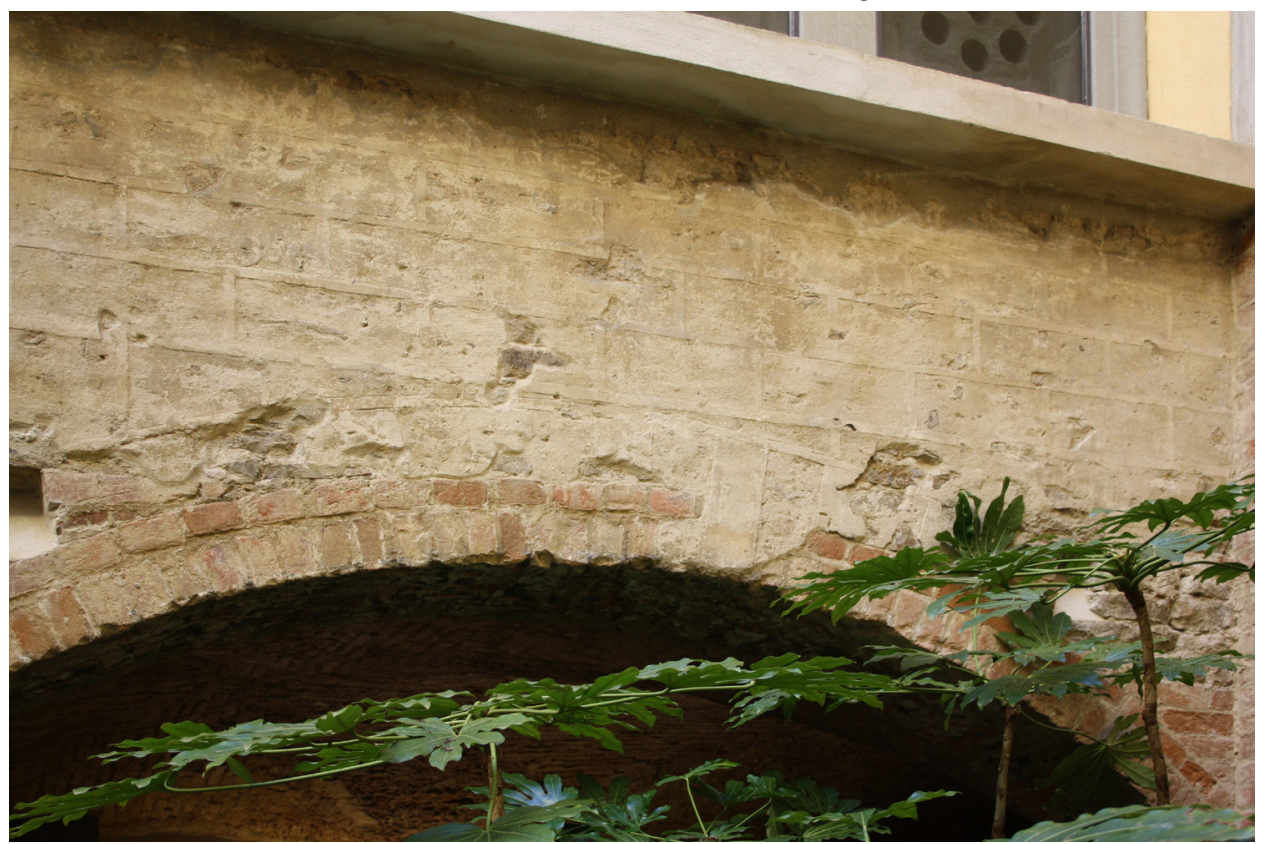

Fig. 7 Chiostro antico, S. Croce, Florence, sgraffito decoration, ca. 1325.

34 The eastern and southern arcades of the so-called Chiostro antico (also referred as Chiostrino antico) were part of a cloister situated between the southern transept of $S$. Croce, the sacristy building. and the first dormitory (destroyed by fire in 1423); Carbonai et al. (2004), 248. The arcades must have been erected around 1325, at the same time or shortly after the completion of the low vaulted ground floor of the sacristy building; Cabassi/Tani (1981), 8 (misdating the sacristy to around 1340). The large, Peruzzi-financed sacristy was completed before 1328, because it was documented as the location for the safekeeping of the election pouches (Giovanni Villani, Nuova Cronica, Lib. 11, Cap. 109; cfr. Moisé (1845), 319; and Davidsohn (1912), 863), introduced during the political reforms of 1328 (cfr. Trexler (1978), 323-4). The sacristy was also mentioned in a testament before 1330 (ASF, Diplomatico, Normali, 5 Gennaio 1329, Firenze, Innocenti; Vojnovic (2007), 297). The dating of the arcades dating before 1328 is confirmed by the start of the building of the Cappella Baroncelli in 1328/29 that took the pre-existing connection between transept, sacristy, and dormitory into account, as can be observed on the ground floor at the powerful L-shaped pillar below the southeastern corner of the chapel (for a different opinion: Saalman (1966), 242, n. 7) and its consideration of the Andito's width. The Andito (or Corridoio) del Noviziato (or della Sagrestia) was probably built in the 1440s; Cabassi/Tani (1982), 284-6. The division of its facade into three large windows does not take into account the rhythm of the pre-existing arcades on the ground floor. 
As demonstrated by this example, from the invention of the sgraffito in early Trecento until mid fifteenth century the plaster was always uncolored. The use of black pigments was probably introduced for the decoration in the courtyard of the Palazzo Medici (Huth, 2016, vol. 1, 64). The new, elegant grey - or "silver" as Vasari later writes ${ }^{35}$ - was intended to harmonize with the walls and the architectonic elements made of grey macigno. The current coloring of the restored courtyard is not reliable proof. ${ }^{36}$ However, many sgraffito decorations in Florence were executed shortly after those of the Palazzo Medici, and they adapted the motifs and coloring of the decorations in the Medici courtyard. ${ }^{37}$ One example is the decoration in Villa La Pietra.

Thanks to an awareness for materiality and technique, this understanding of early sgraffito in Florence opens up possible explorations of hitherto neglected questions-for example in regard to the status and the effects of sgraffito decorations in their urban context, their connections to other artistic fields, or their dissemination throughout Italy and Europe. As this brief excursion into a specific issue makes clear, art history can broaden its horizons through restoration sciences. Of course, this approach is not utterly new, but at least since the so-called "material turn", art history has become highly interested in the significance and the impact of materials, artistic techniques, the processes of execution and - of course - deterioration and alterations. Also, current research on material culture and the "history of things", not only including artifacts but all cultural objects, could not exist without the contributions of the restoration sciences. As a result, it is necessary to increase interdisciplinary cooperation in the interest of both heritage and research.

35 "Scuro che venga in un mezo colore che trae in argentino e verso lo scuro un poco più che tinta di mezo.", Bettarini/ Barocchi (1966-67), vol. 1, Introduzione, Cap. 26, 142-3.

36 The courtyard was restored several times (1902, 1953, and 1992). The current color of the Palazzo Medici sgraffito decoration looks very dark in comparison to other original Florentine sgraffito surfaces.

${ }_{37}$ These include: Palazzo Rucellai (courtyard), sgraffito decoration dating ca. 1455 (largely lost); Palazzo Lapi (facade), sgraffito decoration dating ca. 1455; Residenza dell'Arte della Seta (facade), sgraffito decoration dating ca. 1455-65 (lost); Palazzo Gianfigliazzi (facade), sgraffito decoration dating 1460-61 (lost); Palazzo Tanagli (courtyard), sgraffito decoration dating from the 1460s (largely lost); Palazzo Lenzi (facade), sgraffito decoration dating from the early 1460s (lost); Palazzo Nasi (facade), sgraffito decoration dating from the mid 1460s (restored); Palazzo Vecchietti (courtyard), sgraffito decoration dating from the 1460s (restored); Palazzo della Signoria (courtyard), sgraffito decoration dating 1460-66 (largely lost); Palazzo Benizzi (facade), sgraffito decoration dating 1460-80; Palazzo Niccolò di Giovanni Capponi (facade and courtyard), sgraffito decoration dating 1470-75. See Huth (2016), Diss, vol. 2, cat. no. 22-6, 30-4. 


\section{Bibliography}

Baldinucci, F. (ed. 1845). Notizie dei Professori del Disegno da Cimabue in qua, [1681-1728] ed. by F. Ranalli, Florence: Batelli.

Bandini, F., Danti, C., Lanfranchi, M. R., Matteini, L., Rizzi, M., Ruschi, P., \& Senserini, U. (2001, n.d.). Il graffito quattrocentesco della facciata del Palazzo Gerini-Barbolani di Montauto in Firenze e il suo restauro. In: OPD restauro, 13, 60-89.

Bandini, F., Felici, A. (2014). Il restauro delle pitture murali distaccate dal lato est del Chiostro Verde di Santa Maria Novella a Firenze. In: L. Ciancabilla, C. Spadolini (Eds.) (2014). L'incanto dell'affresco, exh. cat. Ravenna, vol. 2, 107-115.

Becherucci, L., \& Brunetti, G. (1969). Il Museo dell 'Opera del Duomo di Firenze (1, 233-6). Milan: Electa.

Benzi, S., \& Bertuzzi, L. (2006). Il Palagio di Parte Guelfa a Firenze, Florence: University Press Firenze.

Bettarini, R., \& Barocchi, P. (Eds.) (1966-67). Vasari, Giorgio, Le vite de' più eccellenti pittori, scultori e architettori nelle redazioni del 1550 e 1568, Florence: Sansoni.

Bonsanti, G. (1982). Per una politica di restauro a Firenze. In: La città degli Uffizi, Florence, 9598.

Bonsanti, G. (1993). La stagione degli stacchi. Un’eredità difficile da gestire. In: Akten des internationalen Kongresses "Restaurierungsgeschichte" Basel 1991 (1993), 95-99.

Campani, E. (1910). Uccello's story of Noah in the Chiostro Verde. In: The Burlington Magazine, 15, 203-210.

Carbonai, F., Gaggio, G., \& Salmi, M. (2004). Santa Croce - Interpretazione attraverso le indagini metriche e documentaria. In: Rocchi Coopmans De Yoldi, Giuseppe (Ed.). (2004). Santa Maria del Fiore e le chiese fiorentine del Duecento e del Trecento nella città delle fabbriche arnolfiane (Studi e rilievi di architettura medioevale e moderna, 4, 243-62). Florence: Alinea Ed.

Cabassi, S., \& Tani, R. (1981). Il portico della Cappella Pazzi. Nuove ricerche ed ipotesi. Florence: Ed. Città di Vita.

Cabassi, S., \& Tani, R. (1982, n.d.). Il Noviziato di Michelozzo a S. Croce. Città di Vita. 37, 277306.

Ciancabilla, L. (2009). Stacchi e strappi di affreschi tra Settecento e Ottocento. Antologia dei testi fondamentali, Florence: Edifir.

Ciatti, M. (2009). Appunti per un manuale di storia e teoria del restauro, Florence: Edifir.

Davidsohn, R. (1912). Geschichte von Florenz (3, Die letzten Kämpfe gegen die Reichsgewalt). Berlin: Mittler und Sohn.

Felici, A., Pini, S.,Vigna, A. (2008). Il Chiostro Verde nel complesso di Santa Maria Novella a Firenze: storia e restauri. In: OPD restauro, 19, 13-48.

Fineschi, V. (ed. 1977 [1790]). Il Forestiero istruito in S.a Maria Novella. In: Memorie di Santa Maria Novella, Rome. 
Frosinini, C. (ed.) (2019). Il restauro delle pitture murali di Paolo Uccello del Chiostro Verde, Florence: Edifir.

Gualandi, D. (2007). Il restauro di Casa Lapi. In: Comune di Firenze - Ufficio Belle Arti (Ed.) (2007). Cento anni di restauro a Firenze (= Quaderni di restauro, 3, 199-202).

Gurrieri, F. (1998). La Bottega de Benini. Arte e restauro a Firenze nel Novecento, Florence: Edizioni Polistampa.

Huth, A. (2014, n.d.). Albaria insignita. Zur Technologie der Sgraffito-Dekorationen des 15. Jahrhunderts in Florenz, ZKK - Zeitschrift für Kunsttechnologie und Konservierung 28/1, 5-28.

Huth, A. (2016). Florentiner Sgraffito-Dekorationen des 14. und 15. Jahrhunderts (PhD thesis Freie Universität Berlin 2016), 2 vols.

Huth, A. (2014). Grauer Putz, silberne Fassade. Zur Rolle der Kunst in den Sgraffito-Dekorationen des Florentiner Quattrocento. In: Bushart, M., \& Wedekind, G. (2016). Die Farbe Grau (Phoenix - Mainzer kunstwissenschaftliche Bibliothek, 1, 69-87). Berlin: De Gruyter.

Huth, A. (2019). "Degli sgraffiti delle case ..." Die Sgraffito-Technik in Italien von ihrer Entdeckung im Trecento bis zur Wiederaufnahme im 19. Jahrhundert. In: Sgraffito in Change/Sgraffito im Wandel (proceedings of the international conference, HAWK Hochschule Hildesheim/ Holzminden/Göttingen, 2-4 November, 2017, HAWK Hildesheim, Hildesheim 2019 (=Schriften des Hornemann-Instituts, Bd. 19) (forthcoming).

Lillie, A. (2005). Florentine Villas in the Fifteenth Century. An Architectural and Social History. Cambridge: University Press.

Lunardi, R. (1983). Arte e storia in Santa Maria Novella, Florence: Salani.

McAlister, A. (2003). Narrative and Allegory in the Genesis Fresco Cycle in the Chiostro Verde, Santa Maria Novella, Florence, Ph.D. thesis Athens Georgia.

Moisé, F. (1845). Santa Croce di Firenze, Florence.

Panzeri, M. (1998). La tradizione del restauro a Bergamo tra XIX e XX secolo. Mauro Pellicioli un caso paradigmatico. In: Bolltettino d'Arte, suppl. to n. 98, 95-114.

Paolucci (1990). Per una storia del restauro degli affreschi a Firenze: la stagione degli stacchi. In: C. Danti, M. Matteini, M. Moles (Eds.) (1990). Le pitture murali. Tecniche, problemi, conservazione, Florence: Centro Di.

Papaldo, S. (1977). Guido Carroci. In: Dizionario Bibliografico degli Italiani, vol. 20, available online: http://www.treccani.it/enciclopedia/guido-carocci_(Dizionario-Biografico)/ (consulted 5th September 2018).

Procacci, U. (1970). Pitture murali. In: B. Molajoli (Ed.) (1970). Firenze salvata, Turin: ERI, 121-128.

Ragghianti, C.L. (1966). Firenze dopo l'alluvione presente e futuro. In: Critica d'Arte, 83.

Repertorio delle Architetture Civili di Firenze, Palazzo Spinelli Firenze (database). h t t p : / / www.palazzospinelli.org/architetture/ricerca.asp

Rinaldi, S. (1998). I Fiscali, riparatori di dipinti. Vicende e concezioni del restauro tra Ottocento e Novecento, Rome: Lithos. 
Rinaldi, S. (2014). Memorie al magnetofono. Mauro Pellicioli si racconta a Roberto Longhi, Florence: Edifir.

Ruschi, P.: Le ,case dei Neroni nel via del borgo di San Lorenzo. Un'importante vicenda urbana e architettonica a Firenze di metà Quattrocento. In: Benigni, Paola (Ed.) (1996). Palazzo Neroni a Firenze. Storia, architettura, restauro (47-77). Florence: Edifir.

Ruschi, P. (1998). Conferme Michelozziane per il Palazzo di Dietisalvi Neroni a Firenze. In: Morolli, G. (Ed.) (1998). Michelozzo. Scultore e architetto (1396-1472) (215-30). Florence: Centro Di.

Saalman, H. (1966). Michelozzo studies. The Burlington Magazine, 108, 242-250.

Shearman, J. (1967). Le rovine dellarte fiorentina. Ciò che l'alluvione è costata alla civiltà. In: Paragone, 203, 13-33.

Stahlbuhk, K. (2011). Il Chiostro Verde di Santa Maria Novella. I restauri del XX secolo, master thesis Università degli Studi di Siena Facoltà di Lettere e Filosofia di Arezzo AA.2010-2011. Supervisor: Marco Ciatti.

Stahlbuhk, K. (2019). Dipinti Verdi per il Papa. Una nuova interpretazione della Genesi. In: C. Frosinini (Ed.) (2019). Il restauro delle pitture murali di Paolo Uccello del Chiostro Verde, Florence: Edifir.

Thiem, G., \& Thiem, Chr. (1964). Toskanische Fassaden-Dekoration in Sgraffito und Fresko. 14.17. Jahrhundert (= Italienische Forschungen, 3). Munich: Bruckmann.

Trexler, R. C. (1978). Honor among Thieves. The Trust Function of the Urban Clergy in the Florentine Republic. In: Bertelli, S., \& Ramakus, G. (1978). Essays presented to Myron P. Gilmore, (1 - History, 317-34), Florence: La Nuova Italia Ed.

Vojnovic, P. (2007, n.d.). La sacrestia di S. Croce in Firenze. Le sue varie funzioni nel '300. Città di vita, 62, 293-312. 